\title{
Instigarea publică și alte infracțiuni comise prin viu grai în mediul online
}

Av. drd. Dorel Herinean

Facultatea de Drept, Universitatea din București

Motto: , Libertatea ta se termină acolo unde incepe libertatea celuilalt.”

Rezumat: Ținând cont de popularitatea tot mai mare a vloggerilor, a influencerilor și a altor persoane care activează în mediul online, precum și de mediatizarea unor cazuri în care s-a considerat că au fost comise anumite infracțiuni în activitatea acestora care nu s-au bucurat până acum de o atenție deosebită din partea practicii și doctrinei judiciare, materialul reprezintă o succintă analiză a infracțiunii de instigare publică și altora asemănătoare asupra cărora s-a concentrat în această perioadă opinia publică și a circumstanțelor în care acestea pot fi săvârșite.

Cuvinte-cheie: mediul online, instigarea publică, incitarea la ură sau discriminare, incercarea de a determina săvârșirea unei infracțiuni

\section{The public instigation and other crimes that are committed through speech}

\begin{abstract}
Taking into account the growing popularity of vloggers, influencers and other people who perform online, as well as the media coverage of some cases in which certain crimes were considered to have been committed in their activity, crimes which that have not yet enjoyed a special attention from the judicial practice and legal literature, this paper represents a brief analysis of the crime of public instigation and others alike, on which public opinion has been focused during this period, and of the circumstances in which they can be committed.
\end{abstract}

Keywords: online environment, public instigation, incitement to hatred or discrimination, attempting to determine the commission of a crime

\section{Context}

În perioada aceasta au apărut în spațiul public mai multe acuzații și investigații penale care au devenit notorii, acestea vizând norme de incriminare existente și sub imperiul Codului penal 1968, preluate aproape identic în actualul Cod penal, dar care până acum nu au fost aduse în atenţia publică. Mă refer aici la infracțiunile prevăzute în art. 368 C. pen., art. 369 C. pen. și art. 370 C. pen.

Au fost emise multe păreri, mai mult sau mai puțin partizane, legate de textele de incriminare, de aplicarea acestora din punct de vedere material și de măsurile procesuale care au fost luate față de persoanele acuzate de comiterea unor astfel de fapte. 
Notorietatea, influența și succesul tot mai mari ale vloggerilor, influencerilor și ale formatorilor de opinie din mediul online aduc cu sine un flux continuu de doritori care să acceadă la un asemenea statut. Astfel, cum s-a tot repetat în ultima perioadă, oricine poate în zilele noastre să creeze conţinut pe internet, libertatea de exprimare a fiecăruia dintre noi fiind protejată, inclusiv sub acest aspect, de art. 30 din Constituție. Totuși, libertatea aceasta nu este absolută, întrucât, astfel cum o celebră expresie (care a fost atribuită în timp, în diferite forme, mai multor personalități) sintetizează: „Libertatea ta se termină acolo unde începe libertatea celuilalt”.

Fără a îmi propune o analiză exhaustivă a subiectului, cu atât mai puţin una cu caracter transdisciplinar, prin prezentul material voi încerca să clarific, din perspectiva dreptului penal, câteva aspecte legate de aceste norme de incriminare, de rațiunea existenței lor și de modalitatea în care ar putea fi interpretate.

\section{Cadrul legal - norme de incriminare}

\section{Art. 368: Instigarea publică}

(1) Fapta de a îndemna publicul, verbal, în scris sau prin orice alte mijloace, să săvârșească infracțiuni se pedepsește cu închisoare de la 3 luni la 3 ani sau cu amendă, fără a se putea depăși pedeapsa prevăzută de lege pentru infracțiunea la săvârșirea căreia s-a instigat.

(2) Dacă fapta prevăzută în alin. (1) este comisă de un funcționar public, pedeapsa este inchisoarea de la unu la 5 ani și interzicerea exercitării unor drepturi, fără a se putea depăși pedeapsa prevăzută de lege pentru infracțiunea la săvârșirea căreia s-a instigat.

(3) Dacă instigarea publică a avut ca urmare comiterea infracțiunii la care s-a instigat, pedeapsa este cea prevăzută de lege pentru acea infracțiune.

\section{Art. 369: Incitarea la ură sau discriminare}

Incitarea publicului, prin orice mijloace, la ură sau discriminare impotriva unei categorii de persoane se pedepseşte cu închisoare de la 6 luni la 3 ani sau cu amendă.

\section{Art. 370: Încercarea de a determina săvârşirea unei infracţiuni}

Incercarea de a determina o persoană, prin constrângere sau corupere, să comită o infractiune pentru care legea prevede pedeapsa detenţiunii pe viaţă sau pedeapsa închisorii mai mare de 10 ani se pedepseşte cu închisoare de la unu la 5 ani sau cu amendă.

\section{Art. 184: Faptă săvârşită în public}

Fapta se consideră săvârşită în public atunci când a fost comisă:

a) într-un loc care prin natura sau destinaţia lui este totdeauna accesibil publicului, chiar dacă nu este prezentă nicio persoană;

b)în orice alt loc accesibil publicului, dacă sunt de faţă două sau mai multe persoane;

c) într-un loc neaccesibil publicului, însă cu intenţia ca fapta să fie auzită sau văzută şi dacă acest rezultat s-a produs faţă de două sau mai multe persoane; 
d) într-o adunare sau reuniune de mai multe persoane, cu excepţia reuniunilor care pot fi considerate că au caracter de familie, datorită naturii relaţiilor dintre persoanele participante.

După cum se poate observa, deși instigarea publică (art. 368 C. pen.) este vedeta momentului, aceasta nu este singura infracțiune care sancționează forme de determinare la comiterea unor infracțiuni, forme speciale de instigare, existând încă două norme de incriminare care pot fi incidente în situații oarecum similare, astfel cum voi arăta în continuare.

Instigarea, alături de coautorat și complicitate, este o formă a participației penale care presupune determinarea cu intenție a unei alte persoane să săvârșească o faptă prevăzută de legea penală ${ }^{1}$. Actualul Cod penal nu sancționează în Partea generală instigarea neurmată de executare, denumită în doctrină și instigare cu efect negativ ${ }^{2}$, dar o astfel de conduită se poate subsuma unor norme de incriminare distincte ${ }^{3}$, iar textele de la art. 368 și 370 C. pen. au fost introduse tocmai pentru a suplini, cu privire la anumite categorii de fapte și în anumite circumstanțe, acest vid de reglementare lăsat intenționat de legiuitor.

\section{Ce conduite sunt incriminate în concret?}

\section{Instigarea publică}

Această normă de incriminare are în vedere fapta de a îndemna publicul la săvârșirea de infracțiuni. Observăm de la început că, spre deosebire de definiția instigării, unde am arătat că este vorba de o acțiune de determinare, textul de incriminare are în vedere o acțiune de indemnare. În doctrină se arată că ,îndemnul presupune transmiterea cu hotărâre, prin mijloace de comunicare în masă, către public, a unui sfat care se cere a fi urmat. $\underline{\text { Nu este o simplă sugestie. }}$ eventual în glumă, ci un sfat argumentat, (s.n., D. H.) orientat către adoptarea de către public a hotărârii de a săvârși faptele ilicite la care s-a instigat" " Alți autori definesc îndemnul ca o acțiune de instigare explicită la comiterea de infracțiuni ${ }^{5}$.

Doctrina a elaborat și opinia contrară, conform căreia îndemnul ar reprezenta mai puțin decât o determinare $^{6}$, opinie despre care s-a afirmat că ar fi parțial adevărată, întrucât și îndemnul are un

\footnotetext{
${ }^{1}$ L. V. Lefterache, Drept penal, Partea generală. Curs pentru studenții anului II, Ediția a II-a, editura Hamangiu, București, 2018, p. 410.

${ }^{2}$ C-tin. Mitrache, C. Mitrache, Drept penal român, Ediția a III-a, editura Universul Juridic, București, 2019, p. 395.

${ }^{3}$ L. V. Lefterache, op. cit., p. 415; F. Streteanu, D. Niţu, Drept penal. Partea generală, Volumul II, editura Universul Juridic, București, 2018, p. 234.

${ }^{4}$ C. Păun în V. Dobrinoiu, I. Pascu, M. A. Hotca, I. Chiş, M. Gorunescu, C. Păun, M. Dobrinoiu, N. Neagu, M. C. Sinescu, Noul cod penal comentat. Partea specială, Ediția a III-a, revăzută și adăugită, Editura Universul Juridic, București, 2016, p. 921.

${ }^{5}$ V. Dongoroz, Explicații IV, ed. I, 1972, p. 697, apud Nedelcu în G. Bodoroncea, V. Cioclei, I. Kuglay, L. V. Lefterache, T. Manea, I. Nedelcu, F.-M. Vasile, Codul penal. Comentariu pe articole, Ediția 2, Editura C. H. Beck, București, 2016, p. 1213.

${ }^{6}$ T. Vasiliu, D. Pavel, G. Antoniu, D. Lucinescu, V. Papadopol, V. Rămureanu, Codul penal al R.S.R comentat și adnotat. Partea Specială, vol. II, Editura Științifică și Enciclopedică, București, 1975, p. 459, apud C. Păun în V. Dobrinoiu, I. Pascu, M. A. Hotca, I. Chiş, M. Gorunescu, C. Păun, M. Dobrinoiu, N. Neagu, M. C. Sinescu, op. cit., p. 921.
} 
scop precis, respectiv determinarea publicului la săvârșirea unor fapte ilicite ${ }^{7}$. La rândul meu, consider că nu putem pune semnul egalității totale între determinare și îndemn, neputând fi întâmplătoare alegerea legiuitorului de a folosi termeni diferiți, îndemnul putând fi plasat pe o scară inferioară față de determinare, chiar dacă și acesta trebuie să fie îndreptat spre scopul infracțional. În acest sens, suntem de acord cu autorul citat că un îndemn adresat în glumă nu întrunește cerințele necesare pentru a fi incidentă norma de incriminare, trebuind să existe un îndemn serios în acest sens.

Raportat la forma de vinovăţie cu care poate fi comisă fapta, în doctrină se arată că aceasta poate fi comisă atât cu intenție directă, cât și cu intenție eventuală ${ }^{8}$. Acest lucru presupune că, pentru a fi sancționat, autorul ar putea atât să urmărească producerea rezultatului faptei sale (intenția directă), cât și să accepte producerea lui, chiar dacă nu îl urmărește (intenția eventuală).

Mai trebuie menționat că alin. (3) al art. 368 C. pen. stabilește faptul că dacă instigarea a avut ca urmare comiterea infracțiunii la care s-a instigat, pedeapsa va fi cea prevăzută de lege pentru acea infracțiune. Acest text trebuie interpretat în sensul în care este necesară dovedirea unei legături de cauzalitate între instigarea publică și acțiunea eventualului autor, sens în care să se dovedească faptul că aceasta din urmă a comis infracțiunea ca urmare a instigării publice. Cel mai facil mijloc de probă în acest sens ar fi chiar declarația autorului faptei instigate.

În opinia mea, un exemplu de școală privind comiterea acestei infracțiuni este apelul unei persoane la anarhie, la violențe publice necontrolate, îndreptate haotic sau împotriva unor persoane ori categorii de persoane determinate, ori la furtul bunurilor deținute de anumite companii.

\section{Incitarea la ură sau discriminare}

Această infracțiune are în vedere o sferă mai largă de conduite, nefiind circumstanțiate acțiunile ulterioare cu privire la care trebuie să se incite, atâta timp cât acestea se circumscriu noțiunilor de ură şi discriminare a unei categorii de persoane.

Observăm că, spre deosebire de infracțiunea anterior analizată, verbum regens este incitarea, acesta fiind diferit de determinare și îndemnare. În opinia mea, incitarea are un caracter mai puternic decât îndemnul, dar mai slab decât determinarea, fiind o treaptă intermediară. De asemenea, delimitarea categoriilor de persoane poate avea în vedere orice criteriu: clasă socială, etnie, vârstă, sex, apartenență politică, religioasă, socială, categorie profesională, nivel de educație, precum și orice alte criterii pe baza cărora se poate face o delimitare între persoane.

Un exemplu-tip pentru o astfel de infracțiune ar fi un discurs prin care se denigrează o categorie de persoane și sunt încurajați indivizii cărora li se adresează discursul la adoptarea unei atitudinii de marginalizare sau discriminatorie față de acea categorie.

\footnotetext{
7 C. Păun în V. Dobrinoiu, I. Pascu, M. A. Hotca, I. Chiș, M. Gorunescu, C. Păun, M. Dobrinoiu, N. Neagu, M. C. Sinescu, op. cit., p. 921.

${ }^{8}$ S. Bogdan, D. A. Șerban, G. Zlati, Noul Cod penal. Partea Specială. Perspectiva Clujeană, Editura Universul Juridic, București, 2014, p. 711; I. Nedelcu în G. Bodoroncea, V. Cioclei, I. Kuglay, L. V. Lefterache, T. Manea, I. Nedelcu, F.-M. Vasile, op. cit., p. 1213.
} 


\section{Încercarea de a determina săvârșirea unei infracțiuni}

În fine, această ultimă infracțiune privește încercarea de a determina săvârșirea unei infracțiuni de către o persoană, prin constrângere sau corupere. Constrângerea, în opinia mea, la fel ca în cazul infracțiunii de șantaj, poate fi realizată prin violențe, amenințări sau orice alte mijloace prin care se realizează o acțiune de intimidare și o lezare a libertății psihice, chiar dacă nu sunt incriminate separat ca infracțiuni de sine stătătoare ${ }^{9}$. În forma constrângerii, această infracțiune reprezintă o formă specială de șantaj ${ }^{10}$. Noțiunea de corupere, care se poate raporta la textul de incriminare a infracțiunii de luare de mită prevăzută în art. 289 C. pen., are în vedere oferirea sau promisiunea de bani sau alte foloase, indiferent dacă este acceptată sau respinsă ${ }^{11}$.

De esența acestei incriminări este ca încercarea de determinare să privească determinarea la comiterea unei infracțiuni pentru care legea prevede pedeapsa detențiunii pe viață sau pedeapsa inchisorii mai mare de 10 ani. În plus, chiar dacă textul sancționează explicit încercarea de a determina, în mod evident infracțiunea va fi incidentă și dacă această determinare este reușită iniţial, dar apoi persoana nu comite fapta din motive proprii ${ }^{12}$. Totuși, dacă executarea infracțiunii la care s-a determinat este începută, persoana va răspunde în calitate de instigator la acea infracțiune, infracțiunea de la art. 369 C. pen. fiind, în opinia mea, absorbită natural. Motivarea acestei opinii este chiar rațiunea existenței textului, respectiv evitarea lăsării ca nesancționate a încercării de a determina comiterea unei infracțiuni grave, rațiune care nu mai subzistă în cazul în care se comite fapta de către cel instigat. Dincolo de caracterul de infracţiune de pericol al normei de la art. 370, interpretarea contrară ar da naștere unui veritabil caz de bis in idem.

Diferit față de precedentele infracțiuni analizate, această normă de incriminare nu presupune adresarea unui îndemn sau a unei incitări publice, ci poate viza și încercarea de a determina o persoană anume să comită o infracțiune, nefiind însă exclusă modalitatea de comitere în public.

Spre exemplu, directorul unei companii își amenință toți angajații că îi va concedia sau că le va reducere salariului dacă aceștia nu încearcă să ucidă persoanele venite în control la societate. Un alt exemplu, în modalitatea coruperii, ar fi promisiunea oferirii unui bonus financiar consistent persoanei din aceeași companie care reușește să găsească o modalitate nedetectabilă de comitere a unei infracțiuni de evaziune fiscală în forma agravată, prevăzută în art. 9 alin. (3) raportat la alin. (1) din Legea nr. 241/2005.

\footnotetext{
${ }^{9}$ Pentru detalii asupra acestei opinii exprimate cu o altă ocazie, a se vedea D. Herinean, ,Şantajul. Probleme punctuale", p. 20, publicat în Revista Penalmente/Relevant nr. 2/2017, disponibil pe https://www.revista.penalmente.ro/wp-content/uploads/2018/02/Blackmail-and-extortion.-A-few-theoretical-issuesDorel-HERINEAN.pdf, consultat în 17 iunie 2020.

${ }^{10} \mathrm{Cu}$ o altă ocazie, am realizat o analiza extinsă a relației dintre infracțiunile de șantaj și alte infracțiuni. A se vedea D. Herinean, Relația dintre șantaj și alte infracțiuni, publicat în Revista Penalmente/Relevant nr. 1/2018, disponibil pe https://www.revista.penalmente.ro/wp-content/uploads/2018/09/Herinean-blackmail-and-extorsion.pdf, consultat în 17 iunie 2020.

${ }^{11}$ C. Păun, în V. Dobrinoiu, I. Pascu, M. A. Hotca, I. Chiş, M. Gorunescu, C. Păun, M. Dobrinoiu, N. Neagu, M. C. Sinescu, op. cit., p. 926.

${ }^{12}$ În același sens, a se vedea D. A. Șerban, G. Zlati, op. cit., p. 714.
} 
Un exemplu clasic pentru această infracțiune este fapta persoanei care încearcă să angajeze un asasin plătit pentru a ucide o altă persoană.

\section{Cine poate comite astfel de infractiuni?}

Subiectul activ al infracțiunilor de la art. 368 (cu excepția variantei agravate, unde există subiect activ special - funcționarul public), art. 369 și art. 370 C. pen. nu este unul circumstanţiat. Astfel, faptele pot fi comise de către orice persoană fizică sau juridică, atât timp cât acestea pot fi subiecți ai răspunderii penale.

Reamintesc, pe scurt, faptul că în România, de lege lata, minorii sub 14 ani nu răspund penal, iar minorii cu vârsta cuprinsă între 14-16 ani vor răspunde penal doar în măsura în care se va demonstra că aceștia au discernământ. Minorii care au împlinit vârsta de 16 ani vor putea fi trași la răspundere penală cu aceleași limitări precum majorii, existând o prezumție de responsabilitate, care poate fi răsturnată însă în cazul în care minorul nu avea discernământ la data comiterii faptei ${ }^{13}$. Toți minorii care răspund penal beneficiază de regimul sancționator specific, care nu permite aplicarea unor pedepse, ci doar a unor măsuri educative, iar faţă de minorii care nu răspund penal pot fi luate măsuri de ocrotire, în condițiile Legii nr. 272/2004.

$\mathrm{Cu}$ privire la persoanele juridice, Statul și autoritățile publice nu răspund penal, iar instituţiile publice răspund penal doar dacă faptele prevăzute de legea penală sunt comise în cadrul unor activităţi care nu presupun exercițiul puterii publice ${ }^{14}$. De asemenea, persoanele juridice de drept privat vor răspunde atunci când infracțiunile sunt săvârșite în realizarea obiectului de activitate sau în interesul ori în numele persoanei juridice (art. 135 C. pen.).

\section{$\underline{\text { Specificul comiterii infractiunilor în mediul online }}$}

O mare parte din activitatea de comunicare interumană se realizează în mediul online, astfel încât, dată fiind multitudinea de rapoarte juridice interpersonale sau de grup existente pe internet, este normal să apară și conduite ilicite sau chiar ilegale, care să ia forma unor infracțiuni. Chiar dacă de multe ori mediul online oferă protecția anonimatului, în cazul faptelor prevăzute de legea penală, organele judiciare dețin mijloacele tehnice necesare identificării persoanelor implicate, iar o particularitate criminalistică a acestora este că în online mereu rămân și vor rămâne urme digitale ale activităţilor desfăşurate.

Deși marea majoritate a criminalității cibernetice este caracterizată de comiterea infracțiunilor informatice clasice, de tip hacking, într-o accepțiune lato senso, există și alte tipuri de infracțiuni, astfel cum ne-a relevat practica, întâlnite în mediul online, printre care și cele analizate în acest material. Alte norme de incriminare des întâlnite în practică și incidente cu privire la fapte comise

\footnotetext{
${ }^{13}$ Pentru mai multe detalii, a se vedea L. V. Lefterache, op. cit., p. 499 și urm.

${ }^{14} \mathrm{O}$ analiză extinsă a subiectului poate fi regăsită în A.-R. Trandafir (Ilie), Angajarea răspunderii penale a persoanei juridice, Editura C. H. Beck, București, 2011, p. 48 şi urm.
} 
pe internet ar fi șantajul [în special forma asimilată de la art. 207 alin. (2) C. pen. - denumită în limba engleză blackmail], hărțuirea, amenințarea ș.a.

Nu în ultimul rând, faptele comise pe internet de către o persoană care se adresează publicului larg pot conduce la o reacție publică puternică din partea societății, în special a acelora care s-ar simţi lezați de cele arătate, care să creeze contextul unui oprobiu public împotriva autorului și a unui climat ostil raportat la acesta.

\section{$\underline{\text { Observatii generale referitoare la prevenirea comiterii unor astfel de infractiuni }}$}

Vorbitul în public este o chestiune de opțiune personală. Primul lucru pe care trebuie să îl conștientizeze toate persoanele care vorbesc în public, fie că în fața unui public live, fie prin intermediul platformelor de social media, este că sunt pe deplin responsabile de cuvintele pe care le rostesc și că, atunci când alegi să vorbești, astfel cum ne învață filmele de la Hollywood, ,tot ceea ce zici poate fi folosit împotriva ta".

Deși uneori ar putea părea contraintuitiv, există infracțiuni care se comit prin simpla rostire a unor cuvinte, prin viu grai, unele dintre ele fiind prezentate în cadrul acestui material. Codul penal mai prevede și altele, precum amenințarea, șantajul, luarea de mită (în forma pretinderii), dare de mită (în forma oferirii), etc. De altfel, în anumite condiții limitate, chiar și tăcerea unei persoane poate avea valențe penale ${ }^{15}$.

Dincolo de această responsabilitate intrinsecă față de acțiunile proprii a fiecăruia dintre cei care comunică în mod public, nu putem să trecem cu vederea faptul că multe persoane minore dețin variate conturi de social media unde beneficiază de atenția unui număr foarte mare de urmăritori. Or, aceștia sunt mai influențabili decât adulții și, de regulă, au mai puţine pârghii psihice de filtrare a acțiunilor lor. Cu toate acestea, chiar dacă nu au ajuns la o maturizare completă, aceștia trebuie să fie conștienți de faptul că pot fi subiecții răspunderii penale de îndată ce au împlinit vârsta de 14 ani.

Deși libertatea de exprimare este o valoare esențială a democrației și a unui stat de drept, aceasta nu este una absolută. După cum se poate observa, chiar mecanismele dreptului penal, care este ghidat inclusiv de principiul minimei intervenții ${ }^{16}$, sancționează uneori conduite care ar putea părea a fi protejate de libertatea de exprimare a propriilor opinii.

\footnotetext{
${ }^{15}$ Pentru o analiză a tăcerii în dreptul penal, a se vedea prelegerea susținută de A.-R. Trandafir, cu tema ,,Tăcerea în dreptul penal. Valențe ale obligațiilor urgente de sesizare a autorităților”, susținută pe 31 martie 2020 la Conferința online „Urgența în Drept”, organizată de Facultatea de Drept, Universitatea din București. Înregistrarea video este disponibilă pe Canalul Youtube al Facultătiii de Drept. De asemenea, pentru o analiză punctuală a unei astfel de infracțiuni, a se vedea A.-R. Trandafir, Totul e atât de firesc în tăcerea noastră. Sau despre infracțiunea de omisiunea declarării unor informații, publicat în data de 06 aprilie 2020 pe www.juridice.ro, disponibil pe https://www.juridice.ro/679019/totul-e-atat-de-firesc-in-tacerea-noastra-sau-despre-infractiunea-de-omisiuneadeclararii-unor-informatii.html, consultat în data de 17 iunie 2020.

${ }^{16}$ F. Streteanu, D. Nițu, Drept penal. Partea generală, Volumul 1, editura Universul Juridic, București, 2014, p. 63 și urm.
} 
Nu trebuie să uităm că răspunderea penală poate fi atrasă doar pentru faptele comise cu vinovăţie, iar toate infracțiunile prezentate se comit cu intenție (directă sau, în opinia unor autori, cum am arătat, chiar și indirectă). Forma de vinovăție se deduce, de regulă, din elementele obiective ale cauzei.

Or, astfel de fapte pot fi comise uneori în contextul unor glume sau al altor afirmații ori conduite care au ca scop amuzamentul persoanelor sau entertainment-ul în general. Așadar, în aceste cazuri, atunci când o replică ar putea fi riscantă din punct de vedere al celor arătate, consider că ar putea fi arătată în mod neechivoc (fără însă a fi necesară distorsionarea actului artistic) lipsa caracterului serios al acestora de către transmițătorul mesajelor. Într-o astfel de situație a transmiterii neechivoce a caracterului umoristic al afirmației, am serioase rezerve referitoare la posibilitatea reținerii unei intenții, chiar și eventuale, raportată la comiterea unei infracțiuni.

În fine, dincolo de toate aspectele tehnice sau mai puţin tehnice prezentate, consider că atât aplicarea legii, cât și exercitarea drepturilor și libertăților persoanelor trebuie realizate sub umbrela bunei-credințe și a interpretării acestora în concordanță cu scopul pentru care au fost elaborate, respectiv cu scopul pentru care au fost garantate, fără a afecta drepturile celor din jur.

Material a fost publicat în revista online a Facultății de Drept, $\underline{\text { AUBD - Forum Juridic nr. }}$ $\underline{2 / 2020 .}$ 